\title{
Knowledge, attitude and practice towards cervical cancer screening and human papilloma virus vaccine at a tertiary care facility in North India
}

\author{
Devyani Misra $^{1 *}$, Charu Mahajan', Bhumika Bansal ${ }^{2}$
}

\author{
${ }^{1}$ Department of Obstetrics and Gynecology, Dr. Ram Manohar Lohia Institute of Medical Sciences, Lucknow, Uttar \\ Pradesh, India \\ ${ }^{2}$ Consultant Obstetrician, Apollo Medics Hospital, Lucknow, Uttar Pradesh, India
}

Received: 13 May 2020

Accepted: 05 June 2020

\author{
*Correspondence: \\ Dr. Devyani Misra, \\ E-mail: dr.devyanimisra@gmail.com
}

Copyright: () the author(s), publisher and licensee Medip Academy. This is an open-access article distributed under the terms of the Creative Commons Attribution Non-Commercial License, which permits unrestricted non-commercial use, distribution, and reproduction in any medium, provided the original work is properly cited.

\begin{abstract}
Background: Cervical cancer continues to be a major health care problem and most common cause of cancer deaths. Many screening methods are available to detect the disease in precancerous stage. Cervical cancer is the only cancer that is preventable with HPV vaccine against the causative agent responsible for this condition. Knowledge and attitude of women determine the likelihood of women undergoing screening procedures and HPV vaccination which will have implications for the future generations. This study was conducted to determine the knowledge, attitude and practice of women towards cervical screening and HPV vaccine.

Methods: This is a facility based observational cross-sectional study conducted at Dr. RMLIMS, Lucknow, over a period of 3 months - January 2019 to March 2019. Women attending gynecology OPD were enrolled after verbally consenting for the study and were required to fill a pre-structured questionnaire which was then analyzed and assessed.

Results: A total of 368 participants answered the questionnaire. Overall, 154 subjects (41.8\%) had adequate knowledge regarding cervical carcinoma risk factors, symptoms, screening for cancer and HPV vaccine. Favorable attitude was seen in $315(85.5 \%)$ participants. Ninety-six participants $(26.0 \%)$ had ever had a cervical cancer screening and 23 participants $(6.2 \%)$ had ever received HPV vaccine which was very low. Lack of knowledge and cost factors were the main reasons cited for these low screening and vaccination rates among the participants.

Conclusions: The study shows that knowledge was inadequate and screening and vaccination rates were very low in the study population. This highlights the need to educate the community regarding cervical cancer prevention and to make these services readily available at affordable costs to achieve the ultimate goal of elimination of cervical cancer.
\end{abstract}

Keywords: Cervical cancer screening, Human papilloma virus vaccine

\section{INTRODUCTION}

Cervical cancer is a major global health problem being the fourth most common cancer in women worldwide and the most common cause of deaths from cancer in developing countries. According to the Global Cancer Observatory 2018 database, the number of cervical cancer cases reported in the year 2018 were around $5,70,000$ with $3,11,000$ reported deaths related to the disease. Of these 97,000 new cases and 60,000 deaths were reported from India. ${ }^{1}$ This deplorable state exists even though cervical cancer is the only cancer which can be detected early by routine screening and is preventable by human papilloma virus (HPV) vaccination. Cervical cancer occurs at 30-34 years of age and peaks again at $55-65$ years. $^{2}$

The HPV infection is the most important risk factor for cervical intra-epithelial neoplasia and invasive cervical cancer. ${ }^{3}$ Nearly $80 \%$ sexually active women acquire HPV 
infection by the age of 50 years. $^{2}$ The human papilloma virus has over 100 serotypes of which few are oncogenic. Of the high-risk strains, HPV- 16 and HPV- 18 account for $70-75 \%$ of cervical cancer cases and $40-60 \%$ of its precursors. ${ }^{4,5}$ Oncogenic subtypes also cause other cancers like anal, vulvar, vaginal, penile and oropharyngeal cancers. ${ }^{6}$ HPV -6 and HPV-11 serotypes are associated with benign genital infections such as genital warts. ${ }^{7}$ Although presence of HPV infection is essential in causing cancer, the progression from mere infestation to malignancy depends on other cofactors like early initiation of sexual activity, multiple sex partners, tobacco smoking and co-infection with HIV and longterm use of hormonal contraceptives. Co-infection with chlamydia trachomatis and herpes simplex virus type-2, immunosuppression, low socioeconomic status and poor hygiene are some other cofactors. ${ }^{8}$

Conventional screening methods include cervical cytology using the Pap smear and liquid base cytology. Testing for HPV is a more novel screening method which is gaining much popularity. Studies have shown better results with HPV tests than cytology in protection against pre-invasive and invasive cervical cancer. ${ }^{9}$ Though available in India, these screening techniques are underutilized and only a few women are benefitted. This is mainly due to lack of uniformity in health care sectors in urban and rural areas and restricted availability in government sectors owing to enormous costs involved. Also, the vast population makes it nearly impossible to achieve large scale routine screening of the susceptible population.

Two HPV vaccines, a quadrivalent Gardasil@ $(16,18,6$ and 11$)$ and bivalent Cervarix ${ }^{\circledR}(16,18)$ are available and licenced for use. Both these vaccines have near $100 \%$ efficacy. ${ }^{10}$ Although approved by Drug Controller General India in 2008, these vaccines have not been included in the Universal Immunization Programme in India largely due to financial reasons.

HPV vaccine as a method of primary prevention and cervical screening and treatment of early lesions as a method of secondary prevention together can help reduce the huge burden of cervical cancer in India. With this in mind, this study was planned to evaluate knowledge, attitude and practice of cervical cancer screening and HPV vaccine use in the general population.

\section{Aims and objectives}

- To study the demographic details of the participants

- To assess knowledge of participants about cervical cancer etiology, screening and detection, treatment and vaccines for prophylaxis of cancer

- To assess attitude of participants towards cervical cancer screening

- To assess practice of participants regarding routine screening for cervical cancer and HPV vaccination.

\section{METHODS}

The present study is a facility based cross-sectional study conducted at Dr. Ram Manohar Lohia Institute of Medical Sciences, Lucknow, over a period of 3 monthsJanuary 2019 to March 2019. A pre-structured questionnaire was designed based on several studies pertaining to the topic and included information regarding socio-demographic characteristics of the participants. There were 16 questions related to knowledge and 10 questions to assess attitude. Those study participants who had been screened for cervical cancer through Pap smear/HPV test or those who had received HPV vaccine were regarded as having good practice. Knowledge was assessed using a 16-point scale which had dichotomous response i.e. yes or no. Each yes scored 1 and no 0 . A score of $>50 \%$ was considered optimal ( $\geq 8$ positive responses). Attitude was assessed by 10 statements categorized as 4-point scale: strongly agree, agree, disagree, strongly disagree. Attitude was considered favorable if five or more Strongly Agree or Agree responses were obtained.

\section{Inclusion criteria}

- Women attending gynecology OPD for various reasons

- Women consenting to participate in the study.

\section{Exclusion criteria}

- Women not consenting to participate in the study

- Women diagnosed with or history of gynecological malignancies, previously diagnosed abnormal cervical smear reports.

Assuming 50\% optimal knowledge of the population with 95\% confidence interval and 5\% non-response rate, sample size was estimated to be 400 .

The questionnaires were filled by women attending the gynaecology outpatient for various reasons, after giving informed consent.

\section{Statistical analysis}

The filled forms were analysed for results. A response of more than $50 \%$ was considered as good for knowledge and attitude. Descriptive statistics such as Mean \pm SD, frequency and proportion were used for analysis of sociodemographic data and KAP of study population. Determinants of practice were analysed by chi square test with $p$-value $<0.05$ considered statistically significant.

\section{RESULTS}

Response rate in this study was $92 \%(n=368)$. The socio demographic profile of the participants is shown in Table 1. Among 368 participants, around $64 \%$ belonged to urban areas and $50 \%$ were less than 40 years of age. 
Nearly $65 \%$ of study participants were married and had at least 1 child. Eighty four percent had received some form of education. Around $38 \%$ of study population comprised working women and $87 \%$ of the participants were Hindus. Mean age of the study subjects was $29.8 \pm 6.3$ years (SD).

Table 1: Socio-demographic characteristics of the study population.

\begin{tabular}{|c|c|c|}
\hline Variable & $\begin{array}{l}\text { Number } \\
\mathrm{n}=368\end{array}$ & Percentage \\
\hline \multicolumn{3}{|l|}{ Residence } \\
\hline Urban & 235 & $63.8 \%$ \\
\hline Rural & 133 & $36.1 \%$ \\
\hline \multicolumn{3}{|l|}{ Age (years) } \\
\hline $18-39$ & 208 & $56.5 \%$ \\
\hline $40-59$ & 115 & $31.2 \%$ \\
\hline$\geq 60$ & 45 & $12.2 \%$ \\
\hline \multicolumn{3}{|l|}{ Marital status } \\
\hline Married & 242 & $65.7 \%$ \\
\hline Single, divorced, widowed & 126 & $34.2 \%$ \\
\hline \multicolumn{3}{|l|}{ Level of education } \\
\hline Uneducated & 56 & $15.2 \%$ \\
\hline Basic education or above & 312 & $84.7 \%$ \\
\hline \multicolumn{3}{|l|}{ Occupational status } \\
\hline Employed & 142 & $38.5 \%$ \\
\hline Unemployed & 226 & $61.4 \%$ \\
\hline \multicolumn{3}{|l|}{ Religion } \\
\hline Hindu & 321 & $87.2 \%$ \\
\hline Muslim/others & 47 & $12.7 \%$ \\
\hline \multicolumn{3}{|l|}{ Number of children } \\
\hline None & 73 & $19.8 \%$ \\
\hline 1 or more & 295 & $80.1 \%$ \\
\hline \multicolumn{3}{|l|}{ Number of female children } \\
\hline None & 142 & $38.5 \%$ \\
\hline 1 or more & 226 & $61.4 \%$ \\
\hline
\end{tabular}

\section{Knowledge of study subjects}

All participants were aware of cancers in women and that cancer could develop in uterine cervix. The major sources of information were friends and relatives $(45.9 \%)$ as depicted in Figure 1, followed by electronic $(23.6 \%)$ and print media $(15.2 \%)$ and least from health care sector $(7.6 \%)$.

As shown in Table 2, 34\% participants knew of HPV as a causative agent for cancer cervix and more than $50 \%$ of the participants knew about risk factors of cervical cancer. Nearly half of them were aware of some symptom of cervical cancer. Fifty-six percent participants were aware of some form of cervical screening but only $45 \%$ knew early cancer was curable. Nineteen percent participants were aware of the role of HPV vaccine in preventing cervical cancer. Study participants who answered 8 or more questions correctly were considered as having good knowledge. Overall, 154 subjects (41.8\%) had good knowledge regarding cervical carcinoma risk factors, symptoms and screening for cancer and HPV vaccine.

\section{Attitude of study participants}

The questionnaire was used to assess attitude of study participants towards cervical screening and HPV vaccination. Majority of the study participants had positive attitude towards cervical screening and HPV vaccination.

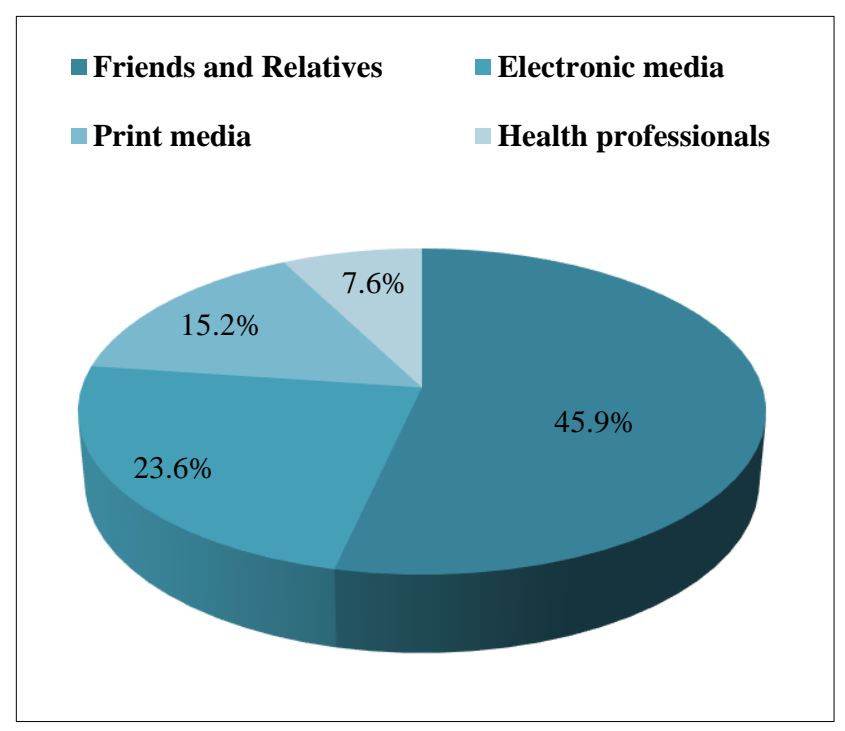

Figure 1: Sources of information about screening tests.

Table 2: Knowledge of cervical cancer risk factors, symptoms, screening and HPV vaccine.

\begin{tabular}{|llllc|}
\hline Knowledge of cervical cancer & Yes frequency & Percentage & No frequency & Percentage \\
\hline Knowledge about risk factors of cervical cancer & & $34.2 \%$ & 242 & $65.7 \%$ \\
\hline $\begin{array}{l}\text { Do you know that human papilloma virus infection is a } \\
\text { risk factor for cervical carcinoma? }\end{array}$ & 126 & $69.0 \%$ & 114 & $30.9 \%$ \\
\hline $\begin{array}{l}\text { Do you know that having multiple sexual partners is a } \\
\text { risk factor for cervical carcinoma? }\end{array}$ & 254 & $53.8 \%$ & 170 \\
\hline $\begin{array}{l}\text { Do you know that having sex at early age is a risk } \\
\text { factor for cervical carcinoma? }\end{array}$ & 198 & $46.1 \%$ \\
\hline
\end{tabular}




\begin{tabular}{|c|c|c|c|c|}
\hline Knowledge of cervical cancer & Yes frequency & Percentage & No frequency & Percentage \\
\hline $\begin{array}{l}\text { Do you know that genital infections could increase risk } \\
\text { of cervical cancer? }\end{array}$ & 237 & $64.4 \%$ & 131 & $35.5 \%$ \\
\hline $\begin{array}{l}\text { Do you know that smoking is a risk factor for cervical } \\
\text { carcinoma? }\end{array}$ & 200 & $54.3 \%$ & 168 & $45.6 \%$ \\
\hline $\begin{array}{l}\text { Do you know having children at an early age and } \\
\text { having many children increases risk of cervical } \\
\text { carcinoma? }\end{array}$ & 149 & $40.4 \%$ & 219 & $59.5 \%$ \\
\hline $\begin{array}{l}\text { Do you know HPV virus causes genital warts and other } \\
\text { cancers too (vulvar cancer, anal cancer, oral and head } \\
\text { and neck, penile cancer in males)? }\end{array}$ & 117 & $31.7 \%$ & 251 & $68.2 \%$ \\
\hline \multicolumn{5}{|l|}{ Signs and symptoms of cervical cancer } \\
\hline $\begin{array}{l}\text { Do you know that foul-smelling vaginal discharge is a } \\
\text { symptom of cervical carcinoma? }\end{array}$ & 205 & $55.7 \%$ & 163 & $44.2 \%$ \\
\hline $\begin{array}{l}\text { Do you know that post coital bleeding is a symptom of } \\
\text { cervical carcinoma? }\end{array}$ & 198 & $53.8 \%$ & 170 & $46.1 \%$ \\
\hline $\begin{array}{l}\text { Do you know that postmenopausal bleeding } \\
\text { (PMB)/intermenstrual/ irregular bleeding is a symptom } \\
\text { of cervical carcinoma? }\end{array}$ & 173 & $47.0 \%$ & 195 & $52.9 \%$ \\
\hline $\begin{array}{l}\text { Do you know that there may not be any symptoms at } \\
\text { all in early stages? }\end{array}$ & 139 & $37.7 \%$ & 229 & $62.2 \%$ \\
\hline \multicolumn{5}{|l|}{ Prevention of cancer cervix } \\
\hline $\begin{array}{l}\text { Are you aware of the screening for cervical cancer? } \\
\text { PAP, LBC, HPV }\end{array}$ & 207 & $56.2 \%$ & 161 & $43.7 \%$ \\
\hline $\begin{array}{l}\text { Do you know that human papilloma virus infection can } \\
\text { be detected without any symptoms? }\end{array}$ & 182 & $49.4 \%$ & 186 & $50.5 \%$ \\
\hline $\begin{array}{l}\text { Do you know that it is possible to detect cancer cervix } \\
\text { in pre-cancer stage with routine screening? }\end{array}$ & 194 & $52.7 \%$ & 174 & $47.2 \%$ \\
\hline $\begin{array}{l}\text { Are you aware cervical carcinoma if detected early is } \\
\text { treatable? }\end{array}$ & 165 & $44.8 \%$ & 203 & $55.1 \%$ \\
\hline $\begin{array}{l}\text { Do you know that it is preventable with a vaccine } \\
\text { against HPV? }\end{array}$ & 69 & $18.7 \%$ & 299 & $81.2 \%$ \\
\hline
\end{tabular}

Table 3: Attitude regarding screening practice and HPV vaccine (frequency and percentage).

\begin{tabular}{|lllll|}
\hline Attitude related questions & $\begin{array}{l}\text { Strongly } \\
\text { agree }\end{array}$ & Agree & Disagree & $\begin{array}{l}\text { Strongly } \\
\text { disagree }\end{array}$ \\
\hline $\begin{array}{l}\text { Cervical cancer is a common cancer in women in India } \\
\text { Any adult woman could develop cervical cancer during her }\end{array}$ & $212(57.6 \%)$ & $141(38.3 \%)$ & $12(3.2 \%)$ & $3(0.8 \%)$ \\
\hline $\begin{array}{l}\text { All wotime } \\
\text { screening }\end{array}$ & $253(66.5 \%)$ & $81(22.0 \%)$ & $29(5.9 \%)$ & $142(3.8 \%)$ \\
\hline Screening can help in early detection of cancer cervix & $149(40.4 \%)$ & $102(27.7 \%)$ & $88(23.9 \%)$ & $29(7.8 \%)$ \\
\hline $\begin{array}{l}\text { Would you go for cervical cancer screening if available free } \\
\text { of cost? }\end{array}$ & $302(82.0 \%)$ & $48(13.0 \%)$ & $10(2.7 \%)$ & $8(2.1 \%)$ \\
\hline $\begin{array}{l}\text { Would you like to go for a cervical if it would cause no } \\
\text { harm }\end{array}$ & $322(87.5 \%)$ & $40(10.8 \%)$ & $2(0.5 \%)$ & $4(1.0 \%)$ \\
\hline $\begin{array}{l}\text { Would you like to go for HPV vaccination after knowing its } \\
\text { role in prevention of cervical carcinoma }\end{array}$ & $295(80.1 \%)$ & $54(14.6 \%)$ & $11(2.9 \%)$ & $8(2.1 \%)$ \\
\hline Would you go for HPV vaccination if available free of cost? & $288(78.2 \%)$ & $31(8.4 \%)$ & $17(4.6 \%)$ & $32(8.6 \%)$ \\
\hline $\begin{array}{l}\text { Would you like to go for HPV vaccination if it caused no } \\
\text { harm }\end{array}$ & $308(83.6 \%)$ & $41(11.1 \%)$ & $9(2.4 \%)$ & $9(2.4 \%)$ \\
\hline Not all women need HPV vaccine & $112(30.4 \%)$ & $97(26.3 \%)$ & $51(13.8 \%)$ & $108(29.3 \%)$ \\
\hline
\end{tabular}

Table 3 depicts attitude of participants towards cervical cancer screening practices and HPV vaccination. Overall favourable attitude was seen in $315(85.5 \%)$ participants. As depicted in Table 3, 68.7\% participants strongly 
agreed that women aged 30-65 years should undergo cervical screening, $82 \%$ strongly agreed to cervical screening if available free of cost, $80 \%$ strongly agreed to HPV vaccination after learning of its role in cervical cancer prevention and $78 \%$ strongly agreed to go for HPV vaccination if available free of cost. Most participants agreed to undergo screening and vaccination if they were harmless.

\section{Practice of study participants}

Table 4 shows 96 participants $(26.0 \%)$ had ever had a cervical cancer screening. Of the $272(73.9 \%)$ who had never had a screening, major reasons cited were lack of knowledge about the tests, cost factor and not knowing who needed the tests.

Table 4: Practice of cervical screening and HPV vaccination.

\begin{tabular}{|lllll|}
\hline Practice related questions & Yes frequency & Percentage & No frequency & Percentage \\
\hline Have you ever had a Pap smear test/ HPV test? & 96 & 26.0 & 272 & 73.9 \\
\hline Have you ever received HPV vaccine? & 23 & 6.2 & 345 & 93.7 \\
\hline
\end{tabular}

Table 5: Chi square analysis of socio-demographic variables and screening practices.

\begin{tabular}{|c|c|c|c|c|}
\hline Variable & Percentage & $\begin{array}{l}\text { Poor screening } \\
\text { practice }(n=272)\end{array}$ & $\begin{array}{l}\text { Good Screening } \\
\text { practice }(n=96)\end{array}$ & $\begin{array}{l}\text { Chi square } \chi^{2} \\
\text { p-value }\end{array}$ \\
\hline \multicolumn{5}{|l|}{ Residence } \\
\hline Urban & $63.8 \%$ & 160 & 75 & 11.45 \\
\hline Rural & $36.1 \%$ & 112 & 21 & $\mathrm{p}<0.05$ \\
\hline \multicolumn{5}{|l|}{ Age (years) } \\
\hline $18-39$ & $56.5 \%$ & 150 & 58 & 10.27 \\
\hline $40-59$ & $31.2 \%$ & 80 & 35 & $\mathrm{p}<0.05$ \\
\hline$\geq 60$ & $12.2 \%$ & 42 & 3 & \\
\hline \multicolumn{5}{|l|}{ Marital status } \\
\hline Married & $65.7 \%$ & 165 & 77 & 12.04 \\
\hline Single, divorced, widowed & $34.2 \%$ & 107 & 19 & $\mathrm{p}<0.05$ \\
\hline \multicolumn{5}{|l|}{ Level of education } \\
\hline Basic education or above & $84.7 \%$ & 238 & 74 & 5.96 \\
\hline Uneducated & $15.2 \%$ & 34 & 22 & $\mathrm{p}<0.05$ \\
\hline \multicolumn{5}{|l|}{ Occupation } \\
\hline Employed & $38.5 \%$ & 62 & 80 & 109.73 \\
\hline Unemployed & $61.4 \%$ & 210 & 16 & $\mathrm{p}<0.05$ \\
\hline \multicolumn{5}{|l|}{ Religion } \\
\hline Hindu & $87.2 \%$ & 237 & 84 & 0.179 \\
\hline Muslim/ others & $12.7 \%$ & 29 & 12 & $\mathrm{p}=0.671^{*}$ \\
\hline \multicolumn{5}{|l|}{ Number of children } \\
\hline 1 or more & $80.1 \%$ & 208 & 87 & 8.93 \\
\hline None & $19.8 \%$ & 64 & 9 & $\mathrm{p}<0.05$ \\
\hline \multicolumn{5}{|l|}{ Female children } \\
\hline 1 or more & $61.4 \%$ & 159 & 67 & 3.84 \\
\hline None & $38.5 \%$ & 113 & 29 & $\mathrm{p}<0.05$ \\
\hline
\end{tabular}

*p value $<0.05$ significant.

As depicted in Table 4, only 23 subjects (6.2\%) had ever received HPV vaccine which was very low. The major reasons cited were lack of knowledge about the vaccine and cost factors. There were also fears of side effects and effects on sexual desire.

All the subjects who had received the HPV vaccine had undergone cervical screening at some time.
Table 5 demonstrated chi square analysis of socio demographic variables and screening practices. As shown in the table, good screening practices were significantly related to urban residence and younger age. Those who were married had higher screening rated compared with single women. Educated and employed women had more cervical screening rates. Participants who had children and especially female child had more screening 
procedures. Screening practices were not affected by religious beliefs of the individual participants.

\section{DISCUSSION}

The study shows that the participants had fair knowledge and favorable attitude towards cervical cancer screening and HPV vaccination even though the number of participants who had ever undergone cervical screening and HPV vaccination were very low.

Factors associated with practice of cervical screening were urban residence, younger age group, those who had children especially female offspring, educated and working women. The major reason for not undergoing screening for cervical cancer was lack of knowledge about the tests. The uptake of HPV vaccine was very low, again majorly due to lack of knowledge and high cost. Religious beliefs of the participants had no bearing on the practices.

In this study, knowledge regarding cervical cancer etiology, symptoms and screening were average. This finding is similar to study done by Gupta RK et al, in north India in 2019, however knowledge of participants is lesser than that reported by Narayana $G$ et al from South India in 2017, and more than that reported by Bansal AB et al in North India. ${ }^{11-13}$ The findings are also similar to studies done by Tran NT et al in Korea. ${ }^{14}$ Though the knowledge of participants regarding cervical screening was average, more than half $(56 \%)$ were aware of some form of screening for cervical cancer. This can be attributed to increased awareness in women due to mass media and increased availability of cervical screening in the urban hospitals. This study reflects that more and more women are becoming conscious about self-care and are taking cognizance of possible early symptoms and reporting early to health care providers. However, despite a fair amount of knowledge regarding cervical cancer etiology, signs and screening, the number of participants who had ever undertaken cervical screening was extremely low (26.0\%).

The main reasons for this can be attributed to lack of infrastructure and uniform quality of health care provided in different regions in India with large dissimilarities in urban and rural settings. Similar findings have been reported by Elizabeth $\mathrm{A}$ et al, which reports screening rate of $29.4 \%$ among Indian women with $34 \%$ in urban areas. ${ }^{15}$ However, the rate of cervical screening is much higher than that reported by Tran NT et al 2011 in Korea. $^{14}$

In this study, $85 \%$ women had favorable attitude towards cervical screening and majority of those willing to get screened were happier if it caused no harm and was done free of cost. However, women still need to be educated regarding implications of this disease so as to motivate them to take up routine screening especially in places where it is available at affordable costs.
Although 34\% women were aware of HPV in cervical cancer etiology and $19 \%$ knew of HPV vaccine, a very small number of women had ever received the HPV vaccine (23 or $6.2 \%$ ). Most of the data available on HPV vaccine is from KAP studies among health care providers and show fair level of knowledge in this cohort. ${ }^{16,17}$ The study by Pandey et al, from North India reports a lower level of awareness (28\%) for the HPV vaccine among women. ${ }^{18}$ Vaccination rates are higher in the private sector compared with public sector 16 and more in developed nations. ${ }^{16,19}$ Lack of knowledge regarding the vaccine, cost factors and lack of acceptability due to certain beliefs about religious practices and sexual implications are the main reasons cited for low vaccination levels. Also myths regarding safety of this vaccine which resulted from unfortunate events during roll-out of vaccine trials in India can be a hindrance in its use. ${ }^{20}$ Nevertheless, studies have shown promising results and possibility of success with cost reducing measures such a single dose vaccination and government funding. ${ }^{20}$ Although the vaccine has long been approved for use by the Drug Controller General, the cost factor stands to be a big obstacle as the vaccine is largely imported for use. The uptake of HPV vaccine in this study was extremely low $(6.2 \%)$. This finding is similar to many studies in India although they have been done in medical students/ health care workers. ${ }^{21}$

This study elucidates the need for community participation in strengthening cervical screening practices and vaccination of young girls to ultimately achieve the aim of elimination of cervical cancer. Also, publicprivate partnership will ensure availability of cervical cancer screening methods and procuring of HPV vaccines at affordable costs. Citing the example of Australia, which was the first country to introduce universal HPV vaccination and routine screening by HPV testing, is estimated to achieve cervical cancer incidence of less than six cases per 1,00,000 women by 2020 and fewer than four per $1,00,000$ by 2028 if the country maintains its current level of coverage of HPV vaccination and screening which have been exemplary. ${ }^{22}$ Implementation of routine cervical screening programmes and HPV vaccination in national immunization schedule can gradually help reduce incidence of cervical cancer and build up herd immunity against HPV. Although achieving such targets will be a long journey through the next few decades, Rome too was not built in a day!

Thus, the need for increasing awareness among women about cervical cancer and providing screening services and HPV vaccines with emphasis on vaccination of potential female children, rest with the clinician as they are the ones directly in contact with the woman and parents are receptive to advices given by doctors about wellbeing of children.

The drawback in this study was that the data was from a tertiary care facility which may not be representative of the general population. Larger surveys need to be done to 
estimate the screening and HPV vaccination rates in the community.

Overall, the study highlights the need for educating the community regarding need for cervical cancer screening methods available at affordable costs. With this in mind authors can take small steps towards the ultimate aim of eliminating cervical cancer.

Funding: No funding sources

Conflict of interest: None declared

Ethical approval: Not required

\section{REFERENCES}

1. Arbyn M, Weiderpass E, Bruni L, de Sanjosé S, Saraiya M, Ferlay J, et al. Estimates of incidence and mortality of cervical cancer in 2018: a worldwide analysis. The Lancet Global Health. 2020;8(2):e191-203.

2. Singh N. HPV and Cervical cancer - prospects for prevention through vaccination. Indian $\mathrm{J}$ Med Paediatr Oncol. 2005;26:20-3.

3. Schiffman M, Castle PE, Jeronim J, Rodrigue AC, Wacholde S. Human papillomavirus and cervical cancer. Lancet. 2007;370:890-907.

4. de Sanjose S, Quint WG, Alemany L. Human papillomavirus genotype attribution in invasive cervical cancer: a retrospective cross-sectional worldwide study. Lancet Oncol. 2010;11:1048-56.

5. Bzhalava D, Guan P, Franceschi S, Dillner J, Clifford G. A systematic review of the prevalence of mucosal and cutaneous human papillomavirus types. Virol. 2013;445:224-31.

6. Dunne EF, Markowitz LE. Genital human Papillomavirus infection. Clin Infect Dis. 2006;43:6249.

7. World Health Organization. HPV IARC monograph summary. Lancet Oncol. 2005;6:204.

8. Castellsague $\mathrm{X}$, Munoz N. Cofactors in human papillomavirus carcinogenesis - role of parity, oral contraceptives, and tobacco smoking. J Natl Cancer Inst Monogr. 2003;31:20-8.

9. Arbyn M, Ronco G, Anttila A, Meijer CJ, Poljak M, Ogilvie G, et al. Evidence regarding human papillomavirus testing in secondary prevention of cervical cancer. Vaccine. 2012;30:F88-99.

10. Kaarthigeyan K. Cervical cancer in India and HPV vaccination. Indian $\mathrm{J}$ Med Paediatr Oncol. 2012;33(1):7-12.

11. Gupta RK, Singh P, Langer B, Kumari R, Sharma P, Gupta RK. Cervical cancer: a hospital based KAP study among women aged 18 years and above in Northern India. Int $\mathbf{J}$ Community Med Public Health. 2019;6:1628-33.

12. Narayana G, Suchitra MJ, Sunanda G, Ramaiah JD, Kumar BP, Veerabhadrappa KV. Knowledge, attitude, and practice toward cervical cancer among women attending obstetrics and gynecology department: a cross-sectional, hospital-based survey in South India. Indian J Cancer. 2017;54(2):481-7.

13. Bansal AB, Pakhare AP, Kapoor N, Mehrotra R, Kokane AM. Knowledge, attitude, and practices related to cervical cancer among adult women: A hospitalbased cross-sectional study. J Natural Sci Biol Med. 2015;6(2):324.

14. Tran NT, Choe SI, Taylor R, Ko WS, Pyo HS, So HC. Knowledge, attitude and practice (KAP) concerning cervical cancer and screening among rural and urban women in six provinces of the Democratic People's Republic of Korea. Asian Pac J Cancer Prev. 2011;12:3029-33.

15. Van Dyne EA. Establishing baseline cervical cancer screening coverage-India, 2015-2016. Morb Mortal Weekly Report. 2019;68:14-9.

16. Chawla PC, Chawla A, Chaudhary S. Knowledge, attitude and practice on human papillomavirus: A crosssectional study among healthcare providers. Indian J Med Res. 2016;144:741-9.

17. Mehta S, Rajaram S. Awareness about human papilloma virus and its vaccine among medical students. Ind J Comm Med. 2013;38(2):92-4.

18. Pandey S, Chandravati. Human papillomavirusmediated cervical cancer awareness and Gardasil vaccination: a pilot survey among North Indian women. J Community Health. 2013;38:907-10.

19. Leung JTC, Law CK. Revisiting knowledge, attitudes and practice (KAP) on human papillomavirus (HPV) vaccination among female university students in Hong Kong. Hum Vaccin Immunother. 2018;14(4):924-30.

20. Sankaranarayanan R, Basu P, Kaur P, Bhaskar R, Singh GB, Denzongpa $\mathrm{P}$, et al. Current status of human papillomavirus vaccination in India's cervical cancer prevention efforts. The Lancet Oncol. 2019;20(11):e637-44.

21. Gaurav A, Bahadur A, Khoiwal K, Bhattacharya N, Chaturwedi J. Knowledge, attitude and practice towards HPV vaccine among medical and nursing students in AIIMS Rishikesh. Indian Obstet Gynaecol. 2019;9(4):34-7.

22. Hall MT, Simms KT, Lew JB, Smith MA, Brotherton JM, Saville M, et al. The projected timeframe until cervical cancer elimination in Australia: a modelling study. Lancet Public Health. 2019;4:e19-27.

Cite this article as: Misra D, Mahajan C, Bansal B. Knowledge, attitude and practice towards cervical cancer screening and human papilloma virus vaccine at a tertiary care facility in North India. Int J Reprod Contracept Obstet Gynecol 2020;9:3004-10. 